\title{
IMPACT OF DIRECT PAYMENTS ON THE DISTRIBUTION AREA - MODEL APPROACH
}

\begin{abstract}
The paper explores the impact of the key types of instruments co-creating the direct support scheme used under the Common Agricultural Policy, i.e. area support, coupled support and historical support, on the income distribution area. The impact of area payments and coupled support on remuneration for factors of production was researched using the model of direct payments transformation into wages, profits and ground rent, and introducing the term of rent-formation coefficient. This also allowed to capture the specificity of historical support.

Identification of the mechanism of direct payments transformation into remuneration of the factors of production was the starting point for analysis of the phenomenon of taking over payments by owners of land and the phenomenon of capitalisation of payments in the price of agricultural land. Moreover, using the partial equilibrium model the paper illustrated the idea behind the phenomenon of taking over payments by buyers of agricultural products.
\end{abstract}

Keywords: direct payments, ground rent, rent-formation coefficient, capitalisation of direct payments.

JEL Cods: H23, Q12, Q24, R38.

\section{Research method and initial assumptions}

The research on the impact of direct support on the distribution area recognised the mechanism of the transformation of direct payments into wages, profits and ground rent. The theoretical bases for the model are two concepts developed under the classical economics: the theory of factors of production and the theory of income distribution. The classical theory of the factors of pro- $\square$ 
duction differentiated only three factors: land, labour and capital (Landreth and Colander, 2005). But then, the theory of distribution as understood by orthodox economics is a theory of payment for factors of production and not a theory of their share in income (Blaug, 1995). Ground rent, i.e. payment for the land factor, is interpreted in the model in line with Ricardo's theory of ground rent (Ricardo, 1957), i.e. as a residual value remaining upon payment for the land and capital inputs. Basing the model on the indicated theoretical fundaments meant acceptance of a number of assumptions of classical concepts. The most important of them are assumptions on rationality of decisions, maximisation of goal function, perfect information and homogeneity of products (Forlicz and Jasiński, 2010).

Using this model, the analysis covered formation of revenues, costs and financial result from plots of different agricultural utility (productivity) and decomposed payment for the factors of production into wages, profits and ground rent, broken down into the part funded by the market and the part funded by the state. The zero variant with no direct support was the starting point for the discussion and the second step involved discussions of an alternative solution, i.e. a variant providing for the use of direct payments. The focus was on the impact of direct support on the level of involvement and payment for respective factors of production, including, on the size of land factor volume and amount of ground rent and structure of its funding. Table description was used to present the interrelations.

The analysis enabled to find regularities concerning the subsidisation level of farming activity depending on the productivity of an agricultural plot and type of support. Apart from that the paper introduced the term rent-formation coefficient of direct payments which allowed to explore the phenomenon of taking over payments by owners of agricultural land and capitalisation of payments in the land price. Moreover, using the partial equilibrium model the paper illustrated the idea behind the phenomenon of taking over coupled support by buyers of agricultural products.

Table 1 presents in detail the initial assumptions of the model. Apart from fixed economies of scale, it was assumed that in the used production method the relationship of labour cost to capital cost is fixed and equals $1 / 3$. The cost of unit portion of labour and capital input is EUR 400. Therefore, in the unit portion of input of the two factors of production, EUR 100 (25\%) is the labour cost and EUR $300(75 \%)$ - the capital cost. Portions of labour and capital input are indivisible. Each plot equals 1 ha. Wheat is cultivated on the plots and its price is EUR 20 per dt. The share of producer in the wheat market is minor, thus from the producer's perspective the wheat demand line is horizontal. Moreover, it was assumed that the costs of securing payments amount to zero (costs involved in application for payments covering in particular non-refinanced costs of services of the agricultural advisory centre). These assumptions were taken uni- 
formly to illustrate the effects of use of both area payments as well as coupled support. The level of support was selected to approximate the total expenditure of the state on aid to farmers (i.e. total amount of subsidisation of agricultural activity) to each other in both cases (EUR 1600). This ensures comparability of the strength of impact of the two forms of aid on the researched variables.

Table 1

Initial assumptions of the model

\begin{tabular}{lc}
\hline \multicolumn{1}{c}{ Economies of scale } & Constans \\
\hline Labour cost & $1 / 3$ \\
Capital cost & EUR 400 \\
Cost of a portion of labour and capital & $L_{A}=L_{B} \cdots=L_{I}=1$ ha \\
Area of an agricultural plot & 20 EUR/dt \\
Wheat price & $\rightarrow 0$ \\
Share of a farm in the wheat market &
\end{tabular}

Source: own study.

The model assumes the standpoint of an agricultural producer, from whose perspective demand is perfectly elastic and payment rate is fixed (price per agricultural product and the support rate do not depend on the farm output volume). Only the analysis of the phenomenon of taking over coupled support by buyers of agricultural products refers not to a single producer but to the entire market (thus the dropping demand curve and payment rate inversely proportional to output volume).

\section{Area support}

Area support is granted to the current area of utilised agricultural area (UAA), i.e. area in the year for which the payment is executed. This group of instruments includes: single/basic payment, single area payment and sectoral area payments ${ }^{1}$.

Single/basic payment is the fundamental component of the system based on entitlements ${ }^{2}$. Whereas single area payment is equivalent to the payment under a simplified system. These are aid instruments of the widest range and thus the most common. A broad range of these payments follows from the fact that

\footnotetext{
${ }^{1}$ This field does not include payments whose rate is expressed in monetary units per hectare, but which are granted not to current utilised agricultural area only to the utilised agricultural area from a specified past period taken as the reference period. This type of payment was classified as historical support and is analysed in the further part of the paper.

${ }^{2}$ Single payment was used as of 2014, and as a result of the 2015 Common Agricultural Policy reform it was replaced by the basic payment.
} 
eligibility for support is available to all lands on which any type of agricultural production is conducted (any crop or livestock grazing) and also lands which are only kept in a state ready for production (cultivation or grazing). Both in the system based on entitlements and the simplified system, apart from support granted to total UAA (i.e. land on which any type of agricultural activity is pursued), sectoral area payments can be applied. This type of support is targeted at cultivation of selected crops, e.g. sugar beets, hoops or cereals. Under the simplified system, the sectoral support is always increased by aid granted to given lands in the form of single area payment. Whereas in the system based on entitlements, accumulation of payments happens only on lands where entitlements were activated.

The model presented below illustrates conversion of area support not coupled with payment entitlements - single area payment typical of the simplified system - into wages, profits and ground rent. It was assumed that the payment rate $P R_{S A P}$ is EUR 200 per ha. The share of a producer in a total UAA covered with payment is minor, therefore from the producer's perspective the payment rate is fixed (independent from the area of land on a farm eligible for payment). Although the single area payment is granted to both UAA on which agricultural production is conducted (any crop or grazing) and UAA which are only kept ready for production (crops or grazing), then - with the given assumptions - the second alternative is not justified because the cost of the lowest possible labour and capital input (EUR 400) is higher than the possible payment to agricultural plot of one hectare (EUR 200) ${ }^{3}$.

Plots marked with subsequent letters of the alphabet are increasingly less fertile - their yield of wheat is lower than the yield of the former plot by $1.5 \mathrm{dt}$ as regards each next portion of labour and capital input. Table 2 presents the product of subsequent portions of labour and capital on respective plots and wheat harvesting from respective plots at the point of producer equilibrium (in the no support variant and variant of support in the form of single area payment).

\footnotetext{
${ }^{3}$ In the conditions of using support, keeping a plot of 1 ha ready for agricultural production brings a loss amounting to EUR 200: revenue equal to EUR 200 (i.e. single area payment amount) does not cover the costs amounting to EUR 400 (hypothetical cost of the lowest possible labour and capital input which will ensure that the plot meets eligibility criteria for single area payment). A better alternative is even abandonment of such activity because then the economic result is 0 .
} 
N
$\frac{0}{0}$
$\frac{\pi}{-1}$

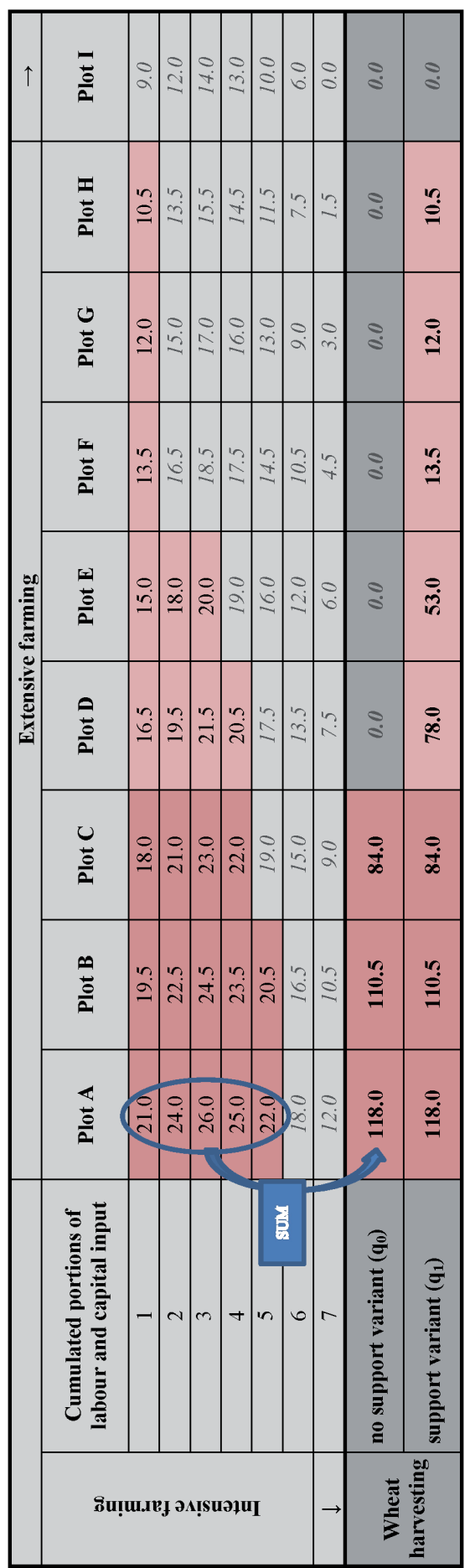

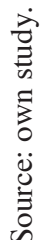


Data on wheat output volume following from its involvement in the production process of subsequent portions of labour and capital input are hypothetical, but they are not completely disconnected from economic practice - realities of cereals yielding in the conditions of the European Union at the current level of agriculture development. From the data it follows that the law of diminishing marginal productivity of land is revealed when the labour and capital input is at the level higher than 3 units. This means that from this moment the increase in total product, following from involvement of subsequent portions of labour and capital, to a given agricultural plot is increasingly smaller. In case of the least fertile plot I, the increase in labour and capital input from 6 to 7 units is not justified (regardless of prices of factors of production and wheat), because it does not bring additional product in the form of increased wheat yield.

With the assumed production function (i.e. the one presented in Table 2, the interrelations between the volume of incurred inputs and achieved output results, measured with the quantity of produced wheat) and assumed prices for factors of production and wheat (in line with the assumptions from Table 1), if no support is used, plots A, B and C will be cultivated (this can be stated based on the matrix of marginal revenues from Table 3 , remembering that the cost of a single portion of labour and capital input is EUR 400) ${ }^{4}$.

Cultivation on the most fertile plots $\mathrm{A}$ and $\mathrm{B}$ will be most intensive -5 portions of labour and capital input will be involved in production on these plots, while on plot $\mathrm{C}-4$ portions will be used. The total cost of these factors of production will thus amount to EUR 2000 for plot A and B, and EUR 1600 for plot C. The yield will amount to $118 \mathrm{dt}$ of wheat from plot A; $110.5 \mathrm{dt}$ - from plot B; and 84 $\mathrm{dt}$ - from plot C, which gives a total revenue on sales in the amount of EUR 2360, EUR 2210 and EUR 1680, respectively. The difference between the total revenue on sales of crops and labour and capital cost, i.e. income on agricultural activity will amount to EUR 360 - for plot A; EUR 210 - for plot B; and EUR 80 - for plot $\mathrm{C}$. In line with the adopted assumption on the ground rent as residual value, this income constitutes payment for the land factor.

\footnotetext{
${ }^{4}$ For example, in case of plot $\mathrm{C}$ the first portion of labour and capital input is given by product with market value at $18 d t \times 20 \frac{E U R}{d t}=E U R 360$, which indeed does not cover the cost which is EUR 400, but respective increase in intensity of production allows to achieve a positive economic result. The second portion of labour and capital input is brought by a product with the value of: $21 d t \times 20 \frac{E U R}{d t}=420 E U R$ the third: $23 d t \times 20 \frac{E U R}{d t}=460 E U R$, and fourth: $22 d t \times 20 \frac{E U R}{d t}=440 E U R$. Involvement of 4 portions of labour and capital input means production at the level of $(18+21+23+22) d t=84 d t$ and ensures total revenue on sales in the amount of $(360+420+460+440) E U R$, with costs amounting to $(4 \times 400) E U R$ $=E U R$ 1600, which means income amounting to $(1680-1600) E U R=E U R 80$. It is optimum (ensuring maximisation of the economic result) production intensity on the plot. Each subsequent portion of labour and capital input gives increasingly lower revenue, not covering the cost of this additional input; hence, increasing inputs above the level of 4 units is not justified.
} 


\begin{tabular}{|c|c|c|c|c|c|c|c|c|c|c|c|c|c|c|c|c|c|c|}
\hline$\uparrow \overrightarrow{\vec{a}}$ & $\mid$\begin{tabular}{c}
8 \\
8 \\
$\infty$ \\
\hdashline
\end{tabular} & 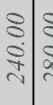 & \begin{tabular}{l|l}
5 \\
5 \\
6 \\
6
\end{tabular} & \begin{tabular}{|l}
8 \\
8 \\
8 \\
\hdashline
\end{tabular} & $\left|\begin{array}{c}8 \\
\vdots \\
\hdashline \\
-1\end{array}\right|$ & $\stackrel{8}{8}$ & $\stackrel{8}{8}$ & 8 & $\uparrow$ & $\overrightarrow{\bar{a}}$ & $\begin{array}{l}8 \\
\vdots \\
0 \\
\infty \\
m\end{array}$ & \begin{tabular}{l|l}
8 \\
0 \\
0 \\
7 \\
\end{tabular} & 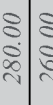 & \begin{tabular}{|c|}
8 \\
8 \\
$\vdots$ \\
\hdashline
\end{tabular} & 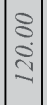 & $\begin{array}{l}8 \\
0 \\
0\end{array}$ & $\stackrel{8}{8}$ & \\
\hline$\frac{\pi}{a}$ & $\left|\begin{array}{c}8 \\
8 \\
2 \\
7\end{array}\right|$ & \begin{tabular}{l|l}
8 & \\
$\vdots$ & \\
&
\end{tabular} & 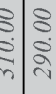 & \begin{tabular}{|l}
8 \\
0 \\
0 \\
\end{tabular} & $\mid \begin{array}{c}8 \\
8 \\
0 \\
-2\end{array}$ & \begin{tabular}{l|l}
8 & \\
$\vdots$ &
\end{tabular} & $:$ & $\frac{8}{8}$ & & $\frac{\pi}{\vec{a}}$ & \begin{tabular}{l}
8 \\
$\vdots$ \\
\hdashline \\
\end{tabular} & $\begin{array}{l}8 \\
0 \\
2 \\
\end{array}$ & \begin{tabular}{l|l}
8 & $\$$ \\
- & $\vdots$
\end{tabular} & $\begin{array}{l}8 \\
8 \\
\check{2} \\
\end{array}$ & \begin{tabular}{|l|}
8 \\
8 \\
2 \\
-2
\end{tabular} & $\begin{array}{l}8 \\
8 \\
\dot{\infty}\end{array}$ & 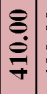 & 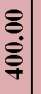 \\
\hline$\frac{0}{a}$ & $\mid \begin{array}{l}8 \\
0 \\
0 \\
2 \\
2\end{array}$ & \begin{tabular}{l|l}
8 & \\
8 & \\
$m$ &
\end{tabular} & 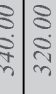 & \begin{tabular}{|l}
8 \\
8 \\
8 \\
1
\end{tabular} & $\begin{array}{l}8 \\
8 \\
2 \\
-1\end{array}$ & \begin{tabular}{l|l}
8 \\
8 \\
8
\end{tabular} & $\begin{array}{l}8 \\
8\end{array}$ & 8 & & $\frac{0}{a}$ & $\begin{array}{l}8 \\
8 \\
+ \\
+\end{array}$ & $\begin{array}{l}8 \\
8 \\
8 \\
\infty\end{array}$ & \begin{tabular}{c|c}
8 & 8 \\
$\vdots$ & 8 \\
$\vdots$ & 8 \\
$m$ & 2
\end{tabular} & $\begin{array}{l}8 \\
8 \\
0 \\
1\end{array}$ & $\mid \begin{array}{l}8 \\
8 \\
2 \\
- \\
-1\end{array}$ & $\begin{array}{l}8 \\
8 \\
8\end{array}$ & 竎 & 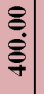 \\
\hline$\frac{5}{\frac{a}{a}}$ & $\left|\begin{array}{l}8 \\
\vdots \\
\vdots \\
2\end{array}\right|$ & \begin{tabular}{c|c}
8 & \\
$\vdots$ & \\
$m$ &
\end{tabular} & \begin{tabular}{c|c}
8 & 8 \\
3 & 8 \\
$m$ & \\
$m$
\end{tabular} & & & & & & & $\frac{5}{E}$ & $\mid \begin{array}{l}8 \\
8 \\
0 \\
\\
\end{array}$ & $\begin{array}{c}8 \\
\dot{2} \\
m\end{array}$ & $\begin{array}{l}8 \\
\vdots \\
\vdots \\
2\end{array}$ & $\mid \begin{array}{l}8 \\
0 \\
0 \\
\vdots \\
1\end{array}$ & $\mid \begin{array}{l}8 \\
\stackrel{2}{2} \\
\end{array}$ & $\begin{array}{l}8 \\
2 \\
2\end{array}$ & 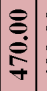 & 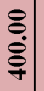 \\
\hline
\end{tabular}

$\frac{0}{2}$

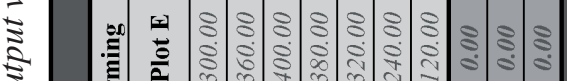

是

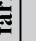

ธิ

.

a 888888

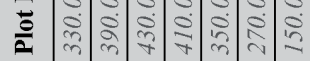

in $m$ f $m m \sim-\mathcal{J}$

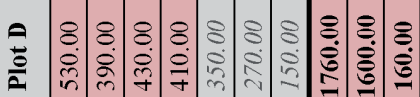

บ 8.8. $8.8 \%$

บ $8.8 .8 .8 .8 \%$

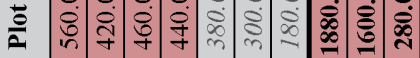

\pm 잉

产

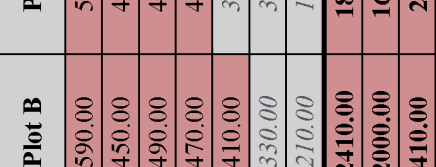

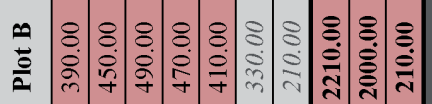

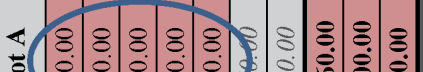

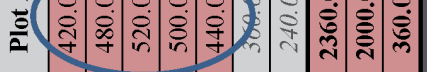

$\vdots$
$\vdots$
$\vdots$
$\vdots$
0
0
0
0
0
5
0

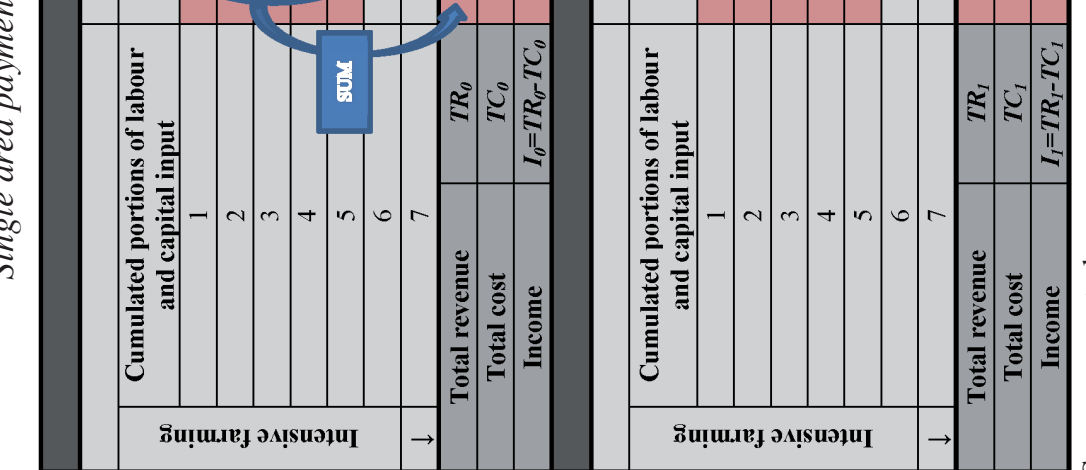

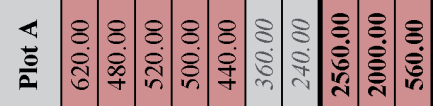


Table 3 presents a matrix of marginal revenues (mathematical products of marginal products from Table 2 and the assumed wheat price) and total revenue (sum of marginal revenues), total cost (mathematical product of the number of involved portions of capital and labour inputs and their assumed price) and income (difference between total revenue and total cost) from respective agricultural plots at the producer point of equilibrium in the no support variant and variant of support in the form of single area payment. As a result of introducing single area payment, the matrix of marginal revenues from the top part of the Table (concerning the no support variant) will change so that the revenues in the first row will increase with the amount of payment available to a given plot. Because all plots have the same area of 1 ha, the amount in case of each of them corresponds to the payment rate. In the analysed case, the single area payment rate (EUR 200 per ha) is sufficiently high to cause a growth in production extensiveness - plots D-H will be put in use. This was presented at the bottom of the Table (concerning support variant).

Production intensity on plots A, B and C will not change, but revenue will increase by the amount of support in the form of single area payment. Income on conducting agricultural activity on the plots, i.e. ground rent, will increase by the same amount ${ }^{5}$.

In case of plots which were included to use as a result of introduction of single area payment, i.e. plots $\mathrm{D}, \mathrm{E}, \mathrm{F}, \mathrm{G}$ and $\mathrm{H}$, revenues on sales of crops would not cover the costs of labour and capital at any level of production (this is why these are not used when area support is not applied). Thus, a part of the single area payment amount will constitute non-market payment for labour and capital. Because ground rent is the residual remaining after covering the costs of labour and capital, only the state will be the source of its funding. The lower the land productivity is, the larger part of the single area payment amount will constitute the payment for labour and capital. This means that along with a drop in land productivity, the market share in payment for labour and capital will decrease, while the share of the state will grow, eo ipso increasingly smaller part of the payment amount will contribute to the ground rent. Table 4 presents the structure of income of respective factors of production in the state of producer equilibrium broken down by the part financed from sales of agricultural products (market) and the part financed from the resources paid under the single area payment (state).

\footnotetext{
${ }^{5}$ Income growth equal exactly to the amount of support results from the adopted assumption on zero costs of securing payments.
} 


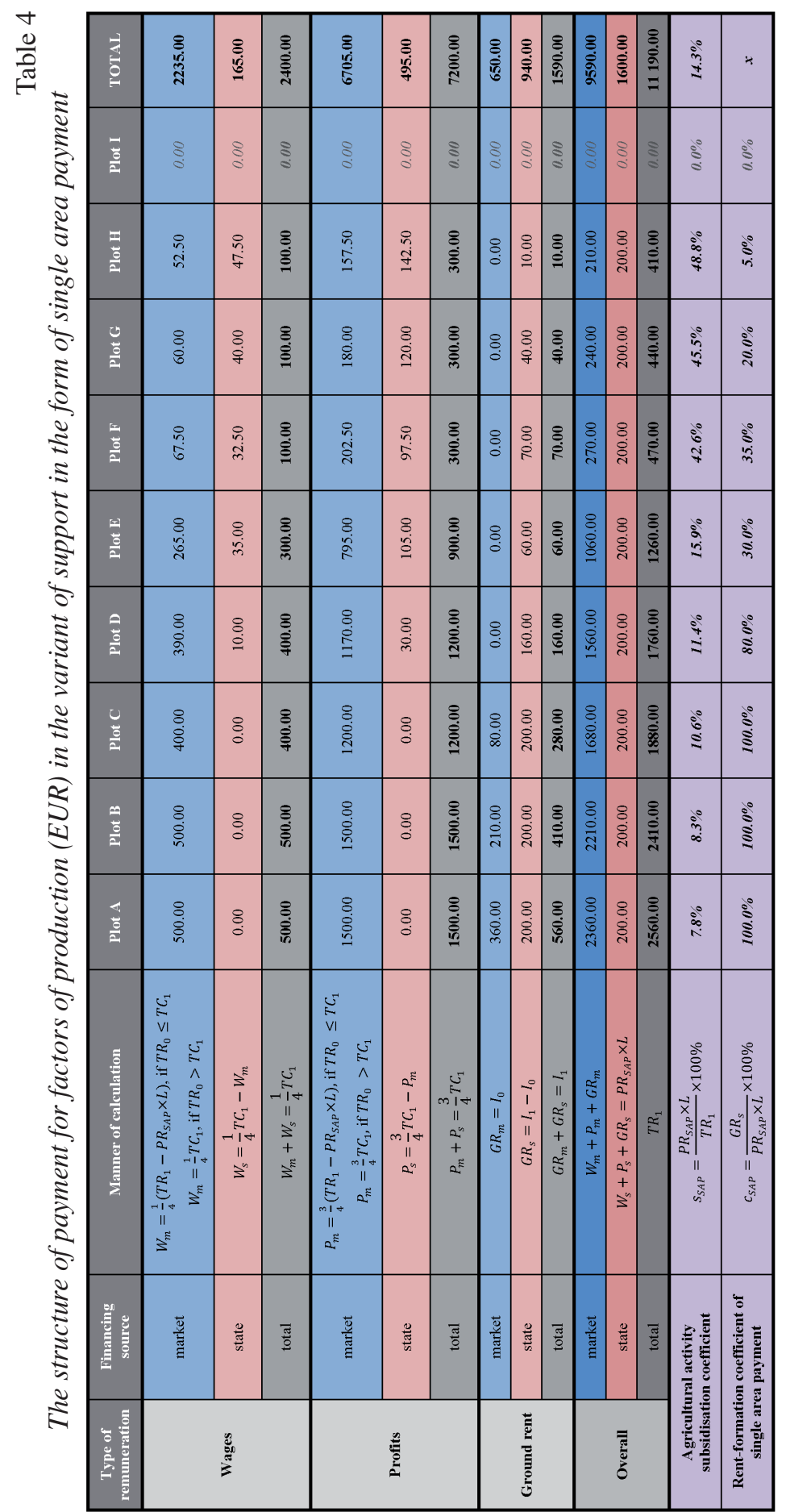

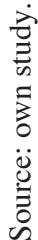


The transformation of the single/basic payment into wages, profits and ground rent is analogous but with the difference that under the impact of these payments there is no growth in production extensiveness, i.e. no additional - against the reference level - plots are included into cultivation.

In the one but last row of Table 4, the values of the agricultural activity subsidisation coefficient $\left(S_{S A P}\right)$ were compared:

$$
s_{S A P}=\frac{P R_{S A P} \times L}{T R_{1}} \times 100 \%
$$

where:

$P R_{S A P}$ - single area payment rate;

$L \quad$ - plot area;

$T R_{I}$ - total revenue (for sales of agricultural products and for single area payment $)^{6}$.

It informs to what extent the remuneration of factors of production is financed by the state. Thus, it is a measure of the relative (i.e. referred to payment for factors of production in total) discrepancy between the total payment for factors of production and the market value of goods manufactured with their use.

This coefficient gets zero value, when payment for the factors of production is the equivalent of manufactured products. This takes place only when the market is the only source of funding of the inputs for factors of production. The value of the coefficient grows along with a drop in the agricultural utility of land, because the smaller the fertility of the agricultural plot, the greater the part of the factors of production is area support. It can maximally achieve $100 \%$ - when no production is conducted on the plot; hence area payments are the only payment for factors of production. In the analysed example, the adopted assumptions exclude such a case (the cost of the smallest possible labour and capital input is higher than the payment amount to agricultural plot of 1 hectare, which means that keeping the land ready for production would not be rational).

The $S_{S A P}$ coefficient can be calculated not only for a specific agricultural plot but also for all lands, dividing the total amount of subsidisation to agricultural activity by the sum of payments for factors of production. For data in Table 4 it is:

${ }^{6}$ For the use of single/basic payment this coefficient is as follows:

$$
S_{S P / B P}=\frac{E P V \times L}{T R_{1}} \times 100 \%
$$

where: $E P V$ - entitlement to payment nominal value activated on a given plot; $L$ - plot area; $T R_{1}$ - total revenue (for sales of agricultural products and for single/basic payment in total). 


$$
s_{S A P}=\frac{1600 E U R}{11190 E U R} \times 100 \% \cong 14.3 \%
$$

whereas the last row of Table 4, compares the values of the rent-formation coefficient of the single area payment $\left(C_{S A P}\right)$ which is as follows:

$$
c_{S A P}=\frac{\Delta G R_{(S A P)}}{P R_{S A P} \times L} \times 100 \%
$$

where:

$\Delta G R\left(_{S A P}\right)$ - increase in ground rent caused by introduction of the single area payment;

$P R_{S A P} \quad$ - single area payment rate;

$L \quad-$ plot area $^{7}$.

This coefficient informs to what extent the support directly contributes to the ground rent.

For example, for plot A, the rent-formation coefficient is:

$$
C_{S A P " A^{n}}=\frac{\text { EUR } 560-\text { EUR } 360}{200 \frac{\mathrm{EUR}}{\mathrm{ha}} \times 1 \text { ha }} \times 100 \%=100 \%,
$$

whereas for plot G:

$$
c_{S A P " G^{n}}=\frac{\text { EUR } 40-\text { EUR O }}{200 \frac{\text { EUR }}{\mathrm{ha}} \times 1 \text { ha }} \times 100 \%=20 \% .
$$

The calculated value of the rent-formation coefficient of respective plots indicates that the single area payment in total increased the ground rent for plots on which production would have been conducted even without the use of support. In case of other plots the share of payments increasing the payment for the land factor is lower than $100 \%$ and decreases along with a drop in plot fertility.

The assumption adopted in the model on rigidity of prices of inputs and products implies stability of agricultural production productivity. Unfavourable business cycle changes can, however, cause that area payment will partly (for pro-

\footnotetext{
${ }^{7}$ Similarly, the rent-formation coefficient of single/basic payment $\left(\mathrm{C}_{\mathrm{SP} / \mathrm{BP}}\right)$ is as follows:

$$
c_{S P / B P}=\frac{\Delta G R_{(S P / B P)}}{E P V \times L} \times 100 \%
$$

where: $\Delta G R_{(S P / B P)}$ - increase in ground rent caused by introduction of the single/basic payment; $E P V-$ entitlement to payment nominal value activated on a given plot; $L-$ plot area.
} 
duction use) or wholly (for keeping ready for production) finance the labour and capital inputs also on lands where production would have been conducted even without the use of support (e.g.: plots A, B and C). How large part of land will be covered by a drop in the value of the rent-formation coefficient depends on the scale of business cycle collapse. To generalise, the value of the rent-formation coefficient of single area payment depends on:

1) Land productivity - in case of land on which (at a given productivity of agricultural production) cultivation or grazing would have been conducted even in case of no area support, payments fully contribute to ground rent, which means that the rent-formation coefficient is $100 \%$, while in case of other lands the share of payments in ground rent formation is lower than $100 \%$ and decreases along with a drop in land productivity;

2) Productivity of agricultural production - a drop in agricultural production productivity will cause a drop in the value of the rent-formation coefficient, which covers a greater part of lands, the stronger is the collapse in the business cycle, but then an increase in production productivity will cause a reverse effect.

The phenomenon of taking over payment by owners of land and the phenomenon of payment capitalisation in the land price emerge because area payments shape the ground rent level.

The phenomenon of taking over payments by owners of agricultural land ${ }^{8}$ happens when land ownership is decoupled from its use. Then, ground rent takes on the form of rental fee paid to the owner of land by the leaseholder (user). Taking over of payments consists in adding part or whole area support to the lease rent.

But then, capitalisation of area payments in land price consists in an increase in land price ${ }^{9}$ following a growth in the stream of discounted income from agricultural land, caused by introduction of these payments. The land seller, getting a higher sales price, takes over a part or whole future stream of "additional" ground rent, i.e. resulting from the use of area support.

Assuming that the share of single area payment contributing to the ground rent will be fixed over the entire period of support use, the increase in the stream of discounted income from an agricultural plot $\left(\triangle D T I_{(S A P)}\right)$ will amount to:

\footnotetext{
${ }^{8}$ The literature often terms the phenomenon as capitalisation of direct payments in the ground rent (Ciaian and Kancs, 2009; Kilian, 2010; Herck, Swinnen and Vranken, 2013; Góral and Kulawik, 2015).

${ }^{9}$ Countries using the system based on entitlements are characterised by land market dichotomy, which consists in trade in lands with entitlements and lands without them. Entitlements to payments are a complementary good against agricultural land and, simultaneously, they are not assigned to specific agricultural plots. Because entitlements can be activated at any lands eligible for payments, trade in entitlements can take place irrespectively of land trade (Figurski and Sadłowski, 2013). As a result, for payments coupled with entitlements, the phenomenon of capitalisation in land price shows, not in a growth in the land price sensu stricto, but rather in the difference between the land price with entitlements and land price without them.
} 


$$
\begin{gathered}
\Delta D T I_{(S A P)}= \\
=L \times\left(\frac{c_{S A P} \times P R_{S A P}(0)}{(1+r)^{0}}+\frac{c_{S A P} \times P R_{S A P}(1)}{(1+r)^{1}}+\frac{c_{S A P} \times P R_{S A P}(2)}{(1+r)^{2}}+\ldots+\frac{c_{S A P} \times P R_{S A P}(n)}{(1+r)^{n}}\right)
\end{gathered}
$$

where:

$L \quad$ - plot area;

$C_{S A P}$ - rent-formation coefficients of single area payment;

$P R_{S A P}(0), P R_{S A P}(1), P R_{S A P}(2), \ldots, P R_{S A P}(\mathrm{n}),-$ single area payment rate in subse-

$r \quad-$ annual interest rate; quent years;

$n+1-$ number of years of using payments ${ }^{10}$.

Rental fee growth resulting from introduction of area payments will correspond to an increase in the annual stream of income caused by the introduction of the payments, while the land price capitalises the entire increase in the stream of future discounted income. Thus, the first component of the sum in the aforementioned formula represents the theoretical increase in rental fee in the first year of use of payments, and the entire sum - theoretical increase in land price, if its sales fall to a year of payment introduction.

The most accurate prediction of the future stream of income on area payments is possible in case of payments coupled with entitlements, especially when the value of entitlements is fixed in the entire period of use of the support system, which takes place in case of the regional and historical model. At the same time, area payments of universal range, i.e. granted to the total area of land on which agricultural activity is conducted, ensure greater predictability of income than the sectoral area support.

Apart from the issues linked to prediction of the future stream of income on account of area support, different institutional conditions influence the process of taking over area payments by owners of agricultural land and capitalisation

${ }^{10}$ Similarly, for single/basic payment the increase in the stream of discounted income from an agricultural plot $\left(\triangle D T I_{(S P / B P)}\right)$ is:

$$
\begin{gathered}
\Delta D T I_{(S P / B P)}=L \times\left(\frac{c_{S P / B P} \times E P V(0)}{(1+r)^{0}}+\frac{c_{S P / B P} \times E P V(1)}{(1+r)^{1}}+\right. \\
\left.+\frac{c_{S P / B P} \times E P V(2)}{(1+r)^{2}}+\cdots+\frac{c_{S P / B P} \times E P V(n)}{(1+r)^{n}}\right)
\end{gathered}
$$

where: $\mathrm{L}$ - plot area; $c_{S P / B P}$ - rent-formation coefficients of single/basic payment; $\operatorname{EPV}(0), \operatorname{EPV}(1)$, $\mathrm{EPV}(2), \ldots, \mathrm{EPV}(\mathrm{n})$ - entitlement to payment nominal value in subsequent years; $r$ - annual interest rate; $n+1-$ number of years of payment use.

If the direct support system does not have an in-build mechanism of convergence of entitlement to payment nominal value, i.e. for implementation models other than the hybrid model, the entitlement to payment nominal value does not change in subsequent years, thus $E P V(0)=E P V(1)=E P V(2)=\ldots=E P V(n)$. 
of these payments in the prices of land. For example, the long-term of lease agreements and their inelasticity lead to inertia of the lease rate preventing the phenomenon of taking over payments by owners of land (Sadłowski, 2012). Whereas restrictions of the right to trade in agricultural property can slowdown the process of capitalisation of payments in the land price.

\section{Coupled support}

Payments to production include all forms of aid executed under the direct support system, whose amount depends on the current output volume or number of owned livestock units (coupled support).

To examine how coupled support undergoes transformation into wages, profits and ground rent the authors used a model which makes the same initial assumption as in the example for area support, but the single area payment rate at EUR 200 per ha was replaced with the coupled support rate to wheat $\left(P R_{q}\right)$ amounting to EUR 3.1 per dt. The share of a farm in the wheat output volume is minor, thus from the perspective of the producer the payment rate is fixed - irrespective of the wheat amount produced on the farm and eligible for payments.

Table 5 presents the increases in the total product resulting from involvement on respective plots of subsequent portions of labour and capital, and wheat harvesting from respective plots at the producer point of equilibrium (for the variant without coupled support and for the variant using coupled support).

The adopted assumptions determine the production process (run of the production function) and market situation (prices of factors of production and products). This, in turn, predetermines the matrixes of marginal revenues and the amount of the total revenue, total cost and income at the point of equilibrium, which were compared in Table 6 (top - for no coupled support variant, bottom - for a variant using support amounting to EUR 3.1 per dt). 


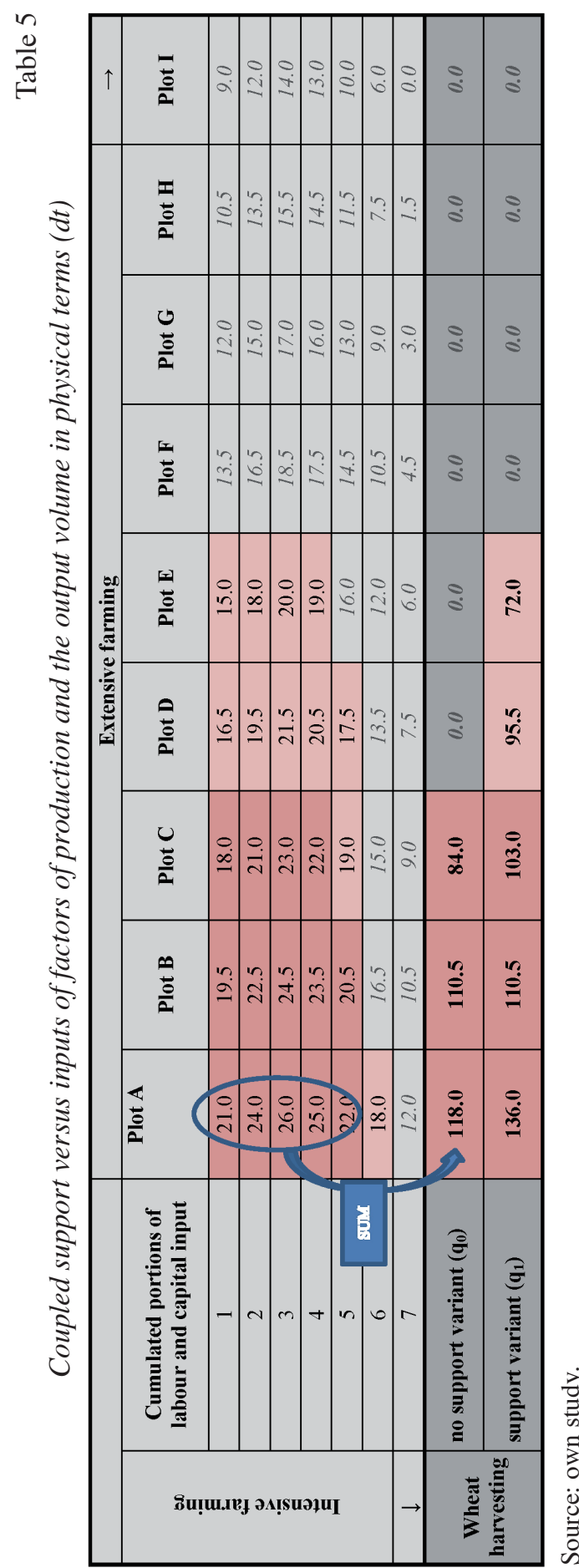


$\frac{6}{\frac{0}{\pi}}$

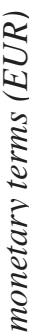

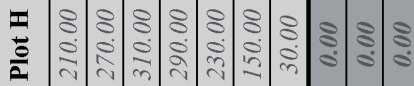

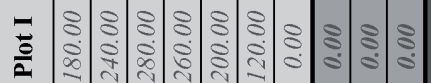

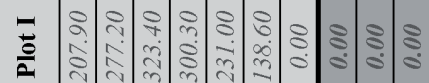

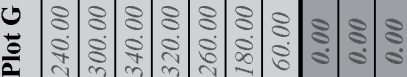

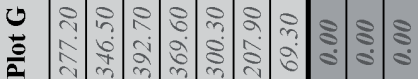

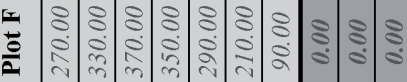

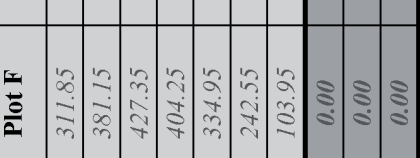

水

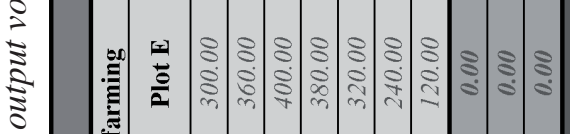

0 )

永

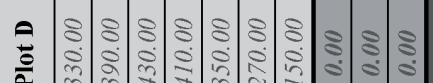

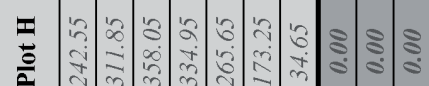

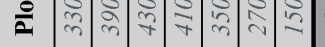

20 된 ㅇำ

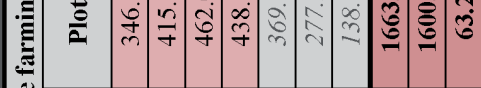

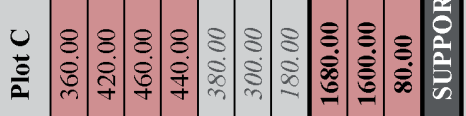

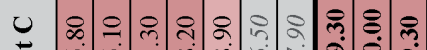

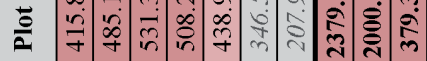

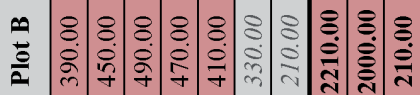

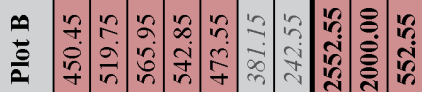

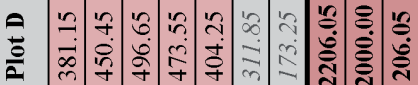

芯

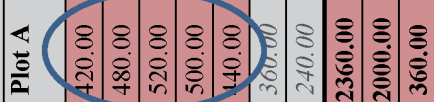

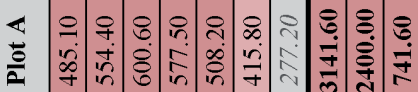

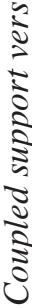
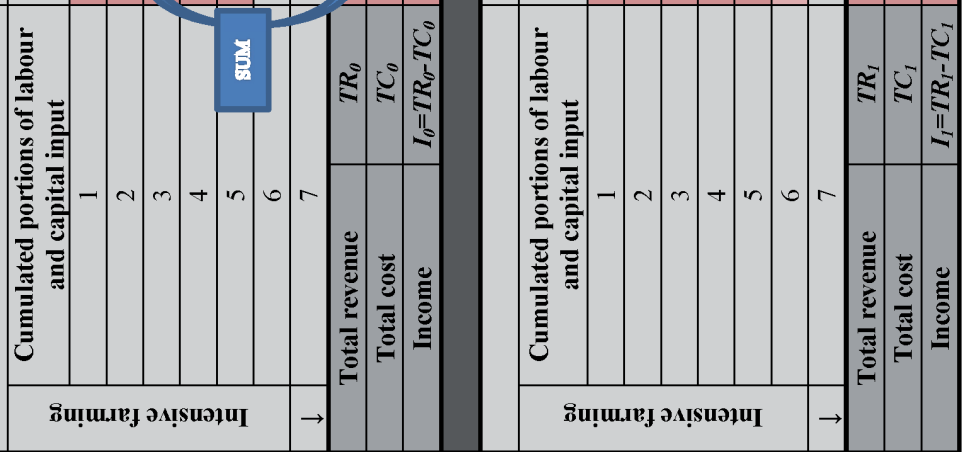

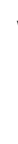

芑

3 
In the reference situation (i.e. no coupled support) wheat is cultivated on plots A, B and C. Production intensity on the most fertile plots A and B is higher -5 portions of labour and capital input is involved in production on these plots, while on plot $\mathrm{C}-4$ portions of the two factors of production are used. Total cost of labour and capital was then EUR 2000 in case of plots A and B, and EUR 1600 in case of plot C. Harvest on plots A, B and C amounts, respectively, to $118 \mathrm{dt}$; 110,5 dt; and $84 \mathrm{dt}$ of wheat and revenue on sales - EUR 2360; EUR 2210; and EUR 1680. Income on agricultural activity, which is the difference between the total revenue on sales of wheat and the cost of labour and capital, will thus amount to EUR 360 - for plot A; EUR 210 - for plot B; and EUR 80 for plot $\mathrm{C}$. This income as a residual value constitutes the remuneration for the land factor, i.e. ground rent.

As a result of introducing coupled support, the marginal revenues from the top part of the Table will grow proportionally to the level presented in the bottom part of the Table. From the compared data it follows that the coupled support boosts production of wheat by increase in both intensity and extensiveness of farming. Increase in production intensity results from higher labour and capital input on plots $\mathrm{A}$ and $\mathrm{C}$, and growth in production extensiveness shows in inclusion into use of plots $\mathrm{D}$ and $\mathrm{E}$.

Table 7 presents the structure of income of respective factors of production by the source of financing and the value of two coefficients describing certain features of the structure. The agricultural activity subsidisation coefficient $\left(s_{Q P}\right)$ indicates to what extent the payment for factors of production is funded by the state. If subsidisation has the form of coupled support, it is actually the relationship between the payment rate, and the sum of the payment rate and the unit price of an agricultural product covered with support expressed in percent. Its value is thus the same for each agricultural plot individually, and for all lands in total. For the analysed example it is:

$$
s_{Q P}=\frac{P R_{q}}{P R_{q}+P} \times 100 \%=\frac{3.1 \frac{E U R}{d t}}{3.1 \frac{E U R}{d t}+20 \frac{E U R}{d t}} \times 100 \%=13.4 \%
$$

where:

$P R_{Q}$ - coupled support rate;

$P \quad$ - price of the product covered with support. 


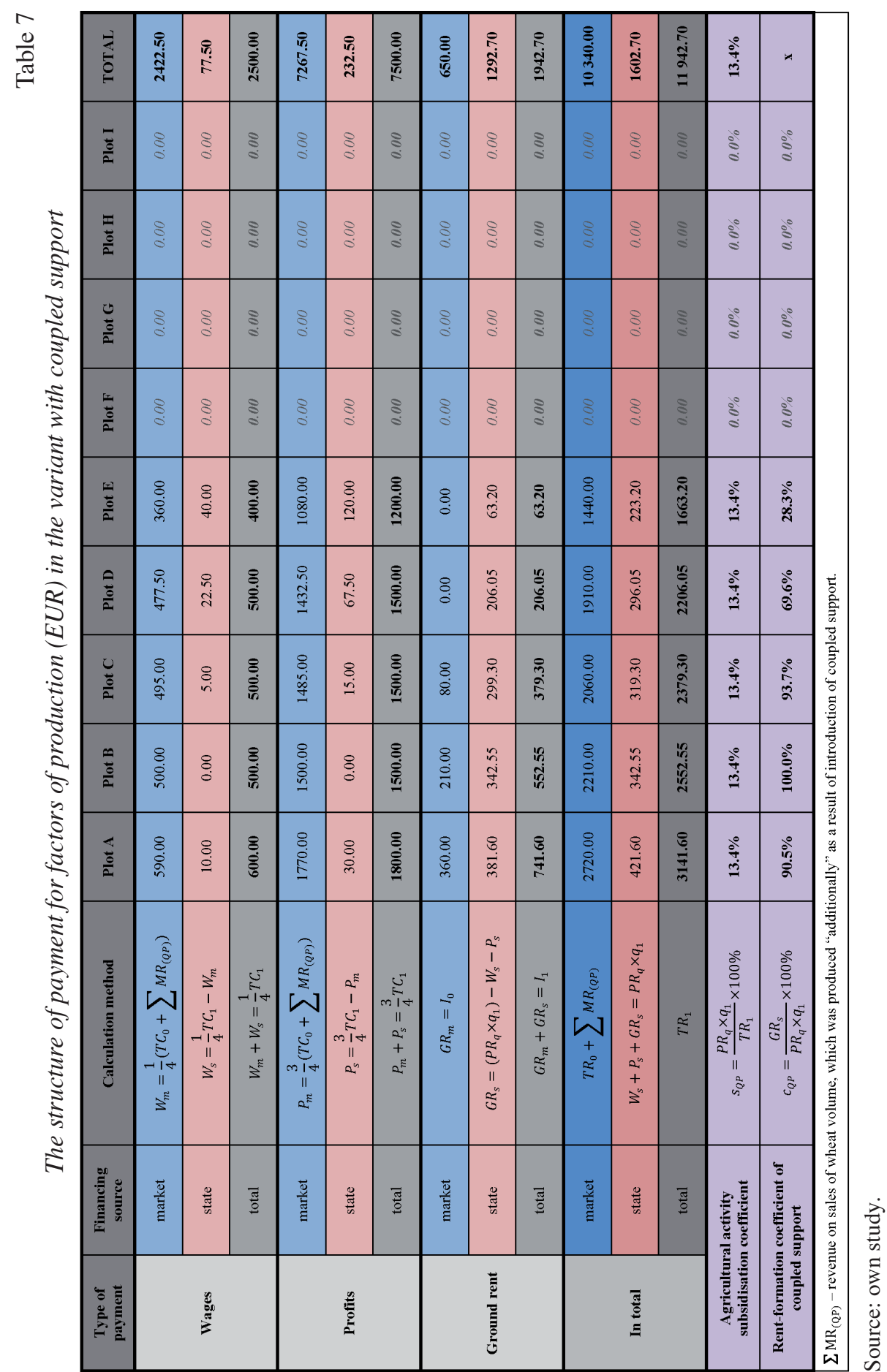


Then the rent-formation coefficient of coupled support $\left(c_{Q P}\right)$ informs to what extent the coupled support contributes to the ground rent. The coefficient is expressed as follows:

where:

$$
c_{Q P}=\frac{\Delta G R_{(Q P)}}{P R_{q} \times q_{1}} \times 100 \%,
$$

$\Delta G R\left(_{Q P}\right)$ - increase in ground rent on a given agricultural plot caused by introduction of coupled support in the plant production sector;

$P R_{q} \quad$ - coupled support rate;

$q_{1} \quad$ - output volume from a given agricultural plot after introduction of support.

For example, for plot $\mathrm{C}$ this coefficient is:

$$
c_{Q P ~} C^{\mathrm{C}}=\frac{\text { EUR } 379.30-\text { EUR } 80}{3.1 \frac{E U R}{d t} \times 103 d t} \times 100 \% \cong 93.7 \%
$$

On plots, on which as a result of introduction of coupled support the production intensity grew (plots A and C), a part of coupled support will finance an additional input of labour and capital and only the remaining part will contribute to the ground rent. The share of coupled support contributing to the ground rent will be the higher the greater is the marginal revenue on sales of agricultural products produced in relation to involvement of additional portions of labour and capital. Similarly, for plots included to production as a result of introduction of the coupled support (plots D and E) a part of the support amount will constitute non-market payment for labour and capital. The share of payments increasing the ground rent will decrease along with a drop in plot fertility, and the ground rent will be fully funded by the state for these plots. Coupled support will contribute to ground rent in exactly $100 \%$ only when production was conducted on a given plot before the payment was introduced, and after its introduction production intensity remained the same. For the analysed example, this happens on plot B. In its case the coupled support amount - equal to EUR 342.55 - will fully contribute to the ground rent.

From the above analysis it follows that coupled support in the plant production sector creates - similarly to area support - remuneration for the land factor (ground rent), although it is not granted to cultivation area only to the quantity of produced crops. However, lack of direct connection between the area of land and amount of granted aid causes that coupled support is less than area payments at risk of being taken over by owners of land and shows weaker tendency to capitalisation in land price. This conclusion is confirmed by results of empirical research conducted in Bavaria which showed intensification in these phenomena because of decoupling of payments (Kilian, Anton, Röder and Salhofer, 2008). 
Fixed price and rate of payment is a consequence of adopting a perspective of a farm of minor share in the market. Analysis at the level of the entire market requires to step back from this simplification, i.e. consideration that the coupled support rate is inversely proportional to output volume ${ }^{11}$. Figure $1-$ using the partial equilibrium model for a market of a product covered with payment presents the effects of introducing the coupled support considering the negative inclination of the market line of demand and changes in the payment rate - opposite in direction - because of changes in output volume. The Figure shows how contractors of farmers on the market of agricultural products covered with support (first buyers of these products in the transaction chain) participate in benefits following from using this form of aid for farmers.

To illustrate the phenomenon of taking over payments by buyers of agricultural products the term of surplus of buyers was used, which is known from macroeconomic theory. This is a difference between the amount that the buyers are willing to pay for a defined quantity of a product and the amount which they actually pay in relation to the applicable market price (Kątowski, 2000). In the graphic interpretation this is the field under the demand curve which is limited from the left with the $0 \mathrm{Y}$ axis, and from the bottom - with a straight line parallel to the $0 \mathrm{X}$ axis, drawn at the height of equilibrium price.

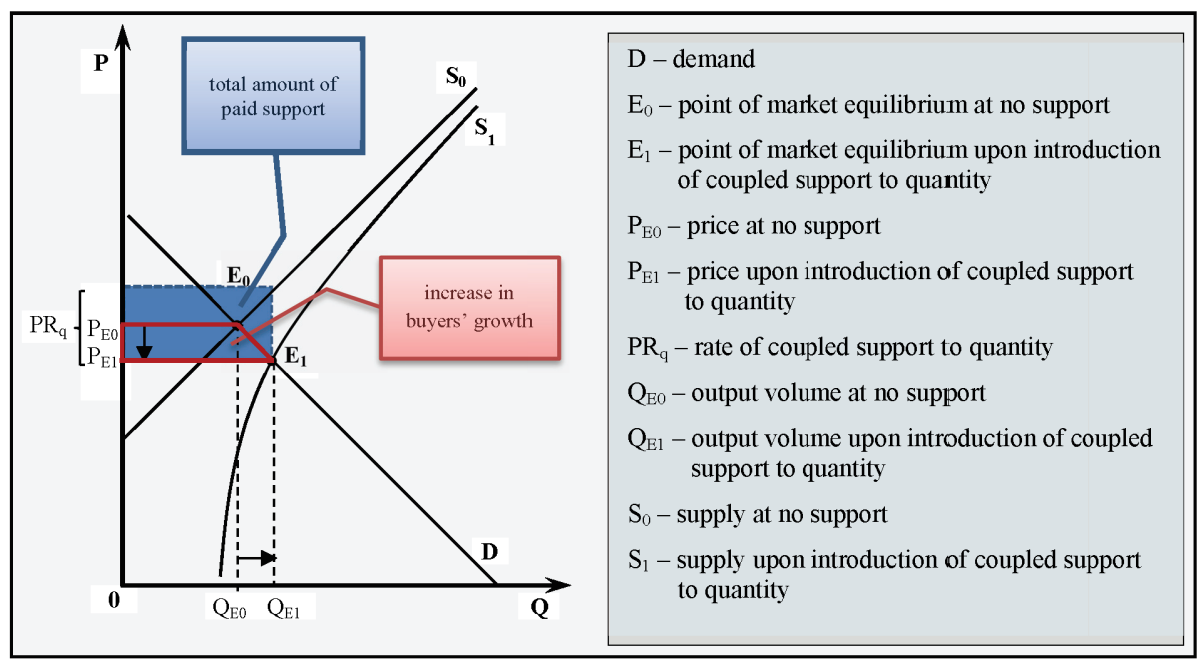

Fig. 1. The phenomenon of taking over coupled support by buyers of agricultural products. Source: own study.

\footnotetext{
${ }^{11}$ Spontaneous drop in the payment rate along with a growth in production acts as a specific automatic stabiliser reducing the stimulating impact of coupled support.
} 
Quantity and price of equilibrium in the initial situation, i.e. at no support, are determined by coordinates of the point of intersection the $\mathrm{D}$ demand line with the $S_{0}$ supply line, thus coordinates of point $E_{0}$. As a result of introduction of coupled support, a new graph of supply function will go below the graph of the primary supply function, and - due to the spontaneous drop in the payment rate along with a growth in the amount of agricultural products covered with support - the shape of the graph will be asymptotically close to the $S_{0}$ line. The market will stabilise with quantity and price marked by the point of intersection of the demand line $\mathrm{D}$ with the $\mathrm{S}_{1}$ supply curve, i.e. at a price lower than the initial level and at higher output volume. From the Figure it follows that a shift to the new point of equilibrium, caused by introduction of coupled support, triggered a growth in the surplus of buyers with the area outlined by a red line of the $\mathrm{P}_{\mathrm{E} 0} \mathrm{P}_{\mathrm{E} 1} \mathrm{E}_{1} \mathrm{E}_{0}$ trapeze.

A ratio based on the price change can be the measure of strengthening phenomenon of taking over coupled support by buyers of agricultural products, which is expressed as follows:

$$
c_{Q P(1)}=\frac{|\Delta P|}{P R_{q}} \times 100 \%
$$

where:

$|\Delta \mathrm{P}|=\left|P_{E 1}-P_{E O}\right|-$ decrease in the price of an agricultural product caused by introduction of coupled support;

$P R_{q} \quad-$ coupled support payment rate.

This coefficient informs to what extent the coupled support was offset by a drop in revenues on sales of a product covered by payments.

Slightly lower values would be taken by an alternative ratio based on a change in the surplus of buyers expressed as follows:

where:

$$
c_{Q P(2)}=\frac{\Delta N N}{P R_{q} \times Q_{E 1}} \times 100 \%
$$

$\triangle N N$ - increase in the surplus of buyers caused by introduction of coupled support;

$P R_{q}$ - coupled support payment rate;

$Q_{E 1}$ - quantity of agricultural products covered with support.

This ratio informs to what extent the total amount of paid coupled support accounts for the growth in the surplus of buyers caused by introduction of the support. 


\section{Historical support}

Historical payments are payments granted to the area of crops or to output volume from the reference period, alternatively to the number of animals owned in the reference period (decoupled support). The reference period is a past period already at the moment of establishment of a given support instrument. Exactly because of this reason the coupling with area of cultivation, output volume or number of owned livestock units in the past, these payments are referred to as historical support.

Award of historical payment is preconditioned (apart from running production in the reference period) only on meeting the so-called minimum requirements for receiving direct payment ${ }^{12}$ and the level of this support depends only on the area of cultivation or on output volume from a reference period. Consequently, historical support does not constitute payment for factors of production, but is a form of purely transfer payments supporting the income of farmers. Therefore, the model of aid conversion into payment for factors of production, which was used for the analysis of area and coupled support, is not applicable as regards historical support. From the above it also follows that historical support is highly resistant to being taken over by both owners of land and buyers of agricultural products. The specificity of historical payments and legal constraints linked to possible award of the payment to a legal successor of a farmer additionally cause that for this type of support the phenomenon of capitalisation can be realised only in the purchase-sales transaction of all production units comprising a farm. Then, it would be possible to take over a part or the entire stream of payments of the future income on account of historical payments by a seller of a farm. Possible capitalisation would thus be realised in the price of all factors of production comprising a farm (and not only in the land price) and on condition that the farm buyer - as a legal successor - would have a right to receive that support.

\section{Conclusions}

As a result of use of the direct support system, the factors of production involved in agriculture generate income above the monetary equivalent of agricultural products created by farms, i.e. expenditure of buyers of agricultural products incurred for their purchase. This additional payment for factors of production used in agriculture - going beyond the monetary equivalent of the produced market goods - is paid by the state exactly as direct payment. Thus,

\footnotetext{
${ }^{12}$ These requirements were determined in Article 10 of the Regulation of the European Parliament and of the Council (2013). Basically in line with paragraph 1 of the Article, Member States decide in which one of the following cases not to grant direct payments to a farmer:
}

a) where the total amount of direct payments (...) in a given calendar year is less than EUR 100;

b) where the eligible area (...) is less than one hectare. 
the direct support system causes redistribution of income against the allocation done as a result of operation of the market mechanism. By influencing the area of income distribution, it is to bridge the gap in the level of life of farmers against the level of life of other professional groups, which results from a permanent income disparity of agriculture as compared to other sectors of the economy (Sobczyński, 2008), and to create incentives to provide public goods (Czyżewski and Kułyk, 2011).

The method and strength of impact of the direct support system on the payment for factors of production in agriculture depends on the significance of respective types of payments under the system. Area support is fully or partly transformed into ground rent. In the second case, the payment - apart from contributing to the payment for the land factor - simultaneously co-finance the input of other factors of production, i.e. labour and capital. The rent-formation coefficient of area support, understood as the share of the amount of this support contributing to the ground rent, is positively correlated with land productivity and productivity of agricultural production. These factors influence the level of payment for the labour and capital inputs in revenues on sales of agricultural products and thus on residual amount of support. Only this residual amount of support, i.e. amount remaining upon coverage of the labour and capital costs, which were not covered by revenues of sales of agricultural products, contributes to the ground rent. This means that the largest part of area support contributes to the ground rent in case of the most fertile UAA and business cycle collapses in agriculture result in a drop in the percentage of payment increasing the payment for the land factor.

If the area support is reflected in the amount of rental fee rates then this is evidence of the phenomenon of taking over of area payments by owners of land. Area payments can also be capitalised in land price. Strengthening of these phenomena depends on many factors which can be divided into two groups:

a) Factors resulting from the very structure of the support instrument, which streamline or hinder the prediction of the stream of revenues from direct payments (coupled or not with entitlements, broadly or narrowly defined categories of land eligible for support);

b) Factors external to the support instrument (these phenomena can be counteracted by e.g. inertia of rental fee rates caused by inelasticity of land lease contracts or inertia of land prices caused by legal constraints in trade in agricultural properties).

Area support, because of the direct coupling of the amount of allocated payment with the UAA is relatively poorly resistant to being taken over by owners of land and to capitalisation in land prices. Therefore, the efficiency of this type of aid as an instrument of support to income of farmers largely depends on the scale of discrepancy between the ownership and use of land. 
Coupled support - similarly to area payments - constitutes a non-market payment for factors of production involved in conducting agricultural activity. If it is directed to the sectors of plant production, it boosts production growth by growth in both intensity and extensiveness of production and fully or partly transforms into ground rent. This can be followed by taking over of coupled support by owners of land or capitalisation of this support in the land price. Nonetheless, because of the lack of direct coupling between the land area and amount of allocated aid, coupled support shows weaker than area payment tendency to create a growth in rental fee rates and to capitalise in land price. But then, a direct coupling between the amount of granted aid and the output volume causes that coupled support is poorly resistant to being taken over by buyers of agricultural products.

Historical support does not affect the volume of input of factors of production on a farm, it constitutes only an incentive to continue agricultural activity - at least to meet the so-called minimum requirements for receiving payments, because only farmers meeting the requirements can be the beneficiaries of direct support. Although the amount of due support is calculated on a case by case basis for respective farms, it does not depend on the current output level or actual profile of conducted activity, but it is predetermined by specific production parameters of farms from a reference period. Consequently, the historical support is the most resistant to the phenomenon of taking over of payments by owners of land and buyers of agricultural products and to capitalisation in land prices. 


\section{Literature:}

Blaug, M. (1995). Metodologia ekonomii. Warszawa: WN PWN.

Ciaian, P., Kancs, D. (2009). The Capitalisation of Area Payments into Farmground rents: Micro Evidence from the New EU Member States. EERI Research Paper Series, No. 4, pp. 1-26.

Council Regulation (EC) No 73/2009 of 19 January 2009 establishing common rules for direct support schemes for farmers under the common agricultural policy and establishing certain support schemes for farmers, amending Regulations (EC) No 1290/2005, (EC) No 247/2006, (EC) No 378/2007 and repealing Regulation (EC) No 1782/2003 (OJ EU L 30, 31.01.2009, p. 16, as amended).

Czyżewski, A., Kułyk, P. (2011). Dobra publiczne w koncepcji wielofunkcyjnego rozwoju rolnictwa; ujęcie teoretyczne i praktyczne. Problemy Rolnictwa Światowego, vol. 11(XXVI), issue 2, pp. 16-25.

Figurski, T., Sadłowski, A. (2013). Ocena systemów płatności bezpośrednich SPS i SAPS W świetle dyskusji nad kształtem WPR po 2013 roku. Journal of Agribusiness and Rural Development, No. 1(27), pp. 63-72.

Forlicz, S., Jasiński, M. (2010). Mikroekonomia. Poznań: Wydawnictwo Wyższej Szkoły Bankowej w Poznaniu.

Góral, J., Kulawik, J. (2015). Problem kapitalizacji subsydiów w rolnictwie. Zagadnienia ekonomiki rolnej, No. 1(342), pp. 3-24.

Kątowski, T. (2000). Podstawowy wykład z mikroekonomii. Gdańsk: Wydawnictwo Uniwersytetu Gdańskiego.

Kilian, S. (2010). Die Kapitalisierung von Direktzahlungen in landwirtschaftlichen Pachtund Bodenpreisen - Theoretische und empirische Analyse der Fischler-Reform der Gemeinsamen Agrarpolitik. Dissertation. München.

Kilian, S., Anton, J., Röder, N., Salhofer, K. (2008). Impacts of 2003 CAP Reform On Land Prices: From Theory To Empirical Results. $109^{\text {th }}$ EAAE Seminar - "The CAP after the Fischler Reform: National Implementations, Impact Assessment and the Agenda for Future Reforms". Viterbo (Italy), 20-21 November 2008.

Landreth, H., Colander, D.C. (2005). Historia myśli ekonomicznej. Warszawa: WN PWN.

Ricardo, D. (1957). Zasady ekonomii politycznej i opodatkowania. Warszawa: PWN.

Regulation (EU) No 1307/2013 of the European Parliament and of the Council of 17 December 2013 establishing rules for direct payments to farmers under support schemes within the framework of the common agricultural policy and repealing Council Regulation (EC) No 637/2008 and Council Regulation (EC) No 73/2009 (OJ EU L 347, 20.12.2013, p. 608, as amended).

Sadłowski, A. (2012). Wpływ płatności bezpośrednich na warunki konkurencji na wspólnym rynku europejskim. Wieś i rolnictwo, No. 2(155), pp. 82-96.

Sobczyński, T. (2008). Zmiany poziomu zrównoważenia gospodarstw rolniczych UE w latach 1989-2005 - implikacje dla Polski. Roczniki Nauk Rolniczych, vol. 94, issue 2, pp. 106-114.

Van Herck, K., Swinnen, J., Vranken, L. (2013). Direct payments and Ground rents Evidence from New Member States. Factor Markets, No. 62, pp. 1-19. 
ADRIAN SADEOWSKI

Szkoła Główna Handlowa

Warszawa

\title{
WPŁYW PŁATNOŚCI BEZPOŚREDNICH NA SFERĘ PODZIAŁU - UJECCIE MODELOWE
}

\begin{abstract}
Abstrakt
W artykule przeprowadzono eksplorację oddziaływania głównych typów instrumentów wspóttworzacych system wsparcia bezpośredniego, stosowany w ramach Wspólnej Polityki Rolnej, tj. wsparcia obszarowego, wsparcia produkcyjnego $i$ wsparcia historycznego, na sfere podziału dochodu. Przy pomocy zbudowanego modelu transformacji płatności bezpośrednich w płace, zyski i rente gruntowa badano wpływ płatności obszarowych $i$ wsparcia produkcyjnego na wynagrodzenie czynników produkcji, wprowadzając pojęcie współczynnika rentotwórczości. Pozwoliło to jednocześnie na uchwycenie specyfiki wsparcia historycznego.

Rozpoznanie mechanizmu transformacji płatności bezpośrednich wwynagrodzenie czynników wytwórczych stanowiło punkt wyjścia dla analizy zjawiska przechwytywania płatności przez właścicieli gruntów rolnych oraz zjawiska kapitalizacji płatności w cenie ziemi rolnej. Ponadto, przy wykorzystaniu modelu równowagi czastkowej, zobrazowano istote zjawiska przechwytywania płatności przez nabywców produktów rolnych.
\end{abstract}

Słowa kluczowe: płatności bezpośrednie, renta gruntowa, współczynnik rentotwórczości, kapitalizacja płatności bezpośrednich.

Accepted for print: 20.04 .2017 .

Unless stated otherwise all the materials on the website are available under the Creative Commons Attribution 3.0 Poland license. Some rights reserved to the Institute of Agricultural and Food Economics - National Research Institute.

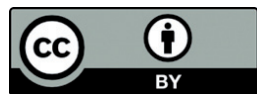

